\title{
Boys and Men: Explorations in Pastoral Theology: Preface
}

\author{
Ryan LaMothe ${ }^{1}$
}

Published online: 12 October 2018

(C) Springer Science+Business Media, LLC, part of Springer Nature 2018

The end of May 2017 was the second year we held an academic conference on Pastoral Theology with Boys and Men at the Presbyterian Historical Society in the Historic District of Philadelphia, Pennsylvania. The idea for a conference on men and boys emerged from conversations between Robert Dykstra and the late Donald Capps several months before Don was tragically killed in a car accident. They imagined a relaxed and collegial gathering of a small number of pastoral theologians who would offer their ideas and research on issues related to boys and men. That they chose to convene the conference in the city of brotherly love is more accident and convenience than deliberate, but nevertheless fitting.

Bob and Don granted attendee freedom to pursue their scholarly interests, which resulted in an eclectic and rich set of papers. Leading off this issue is Rubén Arjona's article, You Are My Friends: Pastoral Care with Young Mexican Men, that explores the importance of male friendship between ministers and young men in pastoral care situations. More specifically, Arjona distinguishes between friendliness and friendship, arguing that in a Mexican cultural context a minister can effectively care for young men who are both parishioners and friends. To illustrate his claims, Arjuna provides a case of a Mexican minister and a young Mexican man. The article challenges those of us from northern climes to consider the idea that male friendship can not only coexist in pastoral care given the power differentials between the pastor and parishioner, but also that it can be helpful to a young male parishioner.

The second contribution to this issue is Danjuma Gibson's article, When Empathy is Not Enough: A Reflection on the Self-Experience of Black Boys in Public Spaces. Given the surfeit of negative images and messages in the media about Black boys (and young men) in Chicago, Gibson considers how African American adolescent boys can obtain more life-giving selfexperiences given the sea of negative stereotypes that are life-limiting. Using the ideas of group-level racial delusion and demonic transference, Gibson argues that at a societal level significant vicious and callous emotional and physical violence is directed at Black boys in public spaces. The negative or demonic transference onto Black boys is accompanied by the

Ryan LaMothe

r.lamothe@saintmeinrad.edu

1 Saint Meinrad Seminary and School of Theology, 200 Hill Drive, Saint Meinrad, IN 47577, USA 
idealization of democratic and Christian values, which further secures the White public's disidentification with African American adolescent boys. These boys, highlighted in Gibson's article, have been policed by the media and carceral state and have, not surprisingly, internalized these negative images. Gibson, in qualitative interviews with African American adolescents in Chicago, identifies ideas for future work in helping these boys resist negative stereotypes and acquire more life-enhancing images.

Today, the Internet brings us millions of erotic images and gifs. In the third article, The Organ of Tactility: Fantasy, Image, and Male Masturbation, Jaco Hamman addresses male solitary masturbation in light of fantasy and image. To illustrate pornography's impact on a male's well-being and neurology, Hamman describes a case of a 17-year-old boy and his excessive use of Internet pornography. In this discussion, Hamman shifts from considering how the discourse on masturbation serves political agendas to the role of sexual fantasy, relying on the wok of British psychoanalyst Brett Kahr. All of this is aimed at discerning whether masturbation is or is not disordered.

The fourth article by Ryan LaMothe is Singing the Blues: Reflections on African American Men, the Emergence of Melancholic Selves, and the Search for Transformational Objects. In this article, I examine the texts of four African American men-Malcolm X, Martin Luther King Jr., James Baldwin, and Ta-Nehisi Coates - arguing that each text manifests the presence of a melancholic self, which arises as a result of internalizing the ubiquitous negative social, political images projections that come from social, political, economic, and cultural disciplinary regimes that support, foster, and enforce racist beliefs (e.g., White superiority, Black inferiority). Like Gibson, I argue that the internalization of negative projections means that some Black children struggle to discover a positive sense of self in the public realm, and it is this ongoing encounter that gives rise to a melancholic faith wherein the child can expect not fidelity, trust, and hope vis-à-vis the public realm but rather betrayal, distrust, and futility vis-àvis the possibility of the world ever presenting to him a positive self. In each of these texts, I note a moment when each author became conscious of racist projections, which initiates a search for a transformational "object" that will liberate him from being in bondage to the melancholic self and its accompanying racial logic and faith. This search, which is a redemptive turn, initiates a process of transforming agency.

Moving from the U.S. context to Asia, Hyon-Uk Shin's article, An Eriksonian PsychoSocial Response to Confucius on the Development of Virtue in Boys and Men, examines the impact of Confucianism on the formation of the psyche and identity of South Korean males. He argues that most males over the last six centuries have identified with and internalized Confucian values of benevolence, righteousness, propriety, wisdom, and sincerity. Unfortunately, this has accompanied under-emphasizing the usefulness and vitality of emotions in men's lives. Using Erik Erikson's view on psychosocial development, Shin argues for a more balanced appropriation of male identity, wherein emotions enrich reason and will, resulting in opportunities for more intimate and caring relations among men.

Remaining in the Korean context, Myounghun Yun rounds out the issue with his article, The Interplay between Korean Men's Movements and Hegemonic Masculinity: Identity, Complicity, and Resistance. Yun identifies three representative types of Korean men's groups and movements, namely, men's rights, conservative evangelical, and profeminist. Within the Korean culture and, more particularly, the discourses of these groups is the often-hidden presence of hegemonic masculinity. In identifying and analyzing the presence of a hegemonic masculinity, Yun turns to consider some future challenges and prospects for a profeminist politics of masculinity. 
Before ending, let me first offer my thanks to Robert Dykstra and Nathan Carlin. They organized and hosted this conference with their typical scholarly acumen, good humor, and hospitality. I also want to thank Lewis Rambo who has been open to publishing the papers given at the conference of Pastoral Theology with Boys and Men. Finally, I wish to thank the people at the Presbyterian Historical Society who provided the space for us to meet. They exemplify the best values of a city of brotherly and sisterly love. 